\title{
Associations of non-breeding shearwater species on the northeastern Newfoundland coast
}

\author{
Paloma C. Carvalho*, Gail K. Davoren
}

University of Manitoba, Winnipeg, MB R3T 2N2, Canada

ABSTRACT: Prey aggregations are not uniformly distributed, driving predator species to aggregate in specific areas of high food availability. On the east coast of Newfoundland, capelin Mallotus villosus, a small forage fish, migrate inshore to spawn during the summer, providing an abundant food source for marine predators. During this period, non-breeding great shearwaters Ardenna gravis (GRSH) and sooty shearwaters A. grisea (SOSH), both long-distance migratory seabirds, aggregate in coastal Newfoundland, but it is unclear what drives their distributional patterns within this region. Using at-sea surveys, we investigated whether the density and distributional patterns of GRSH or SOSH were influenced by sea surface temperature, depth and fish (prey) density as well as the number of the other seabird species or other shearwater species (i.e. GRSH or SOSH). The presence and number of GRSH and SOSH were positively influenced by the density of the other sympatric shearwater species but were not influenced by the densities of other seabird species. These findings suggest that the benefits of foraging in close association may outweigh costs. Fish density was less important in explaining the presence and number of GRSH and SOSH than depth, as both species were mainly found together in shallow areas $(<50 \mathrm{~m})$ along the coast. As fish density was primarily distributed in shallow areas, reflecting predictable locations of and migratory routes to capelin spawning sites, depth (or distance from shore) and the distribution of other shearwaters may provide important cues to locate regions of high prey availability in coastal Newfoundland.

KEY WORDS: Seabird distribution - Shearwater . Local enhancement . Capelin . Mallotus villosus . Predator-prey

\footnotetext{
*Corresponding author: ccpaloma@gmail.com
}

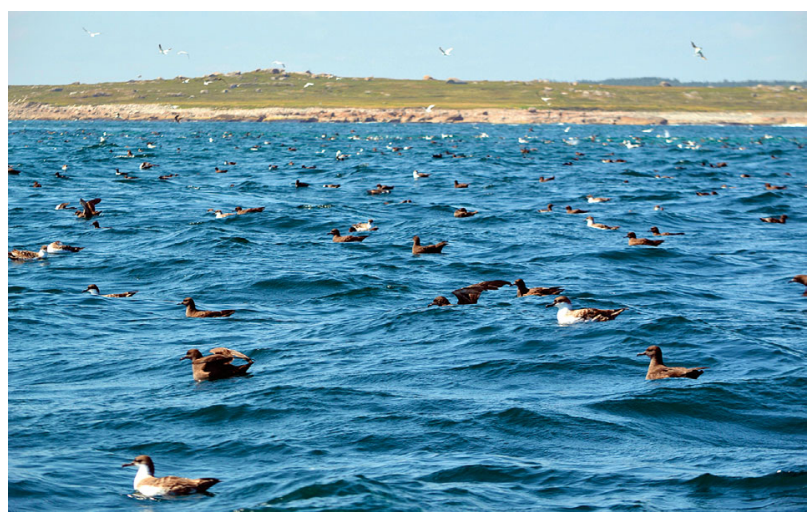

An aggregation of non-breeding great and sooty shearwaters close to shore in coastal Newfoundland, Canada.

Photo: Julia Gulka

\section{INTRODUCTION}

Areas of high productivity are not uniformly distributed in most environments, and predators tend to concentrate in areas where environmental factors are favourable, such as patches of high food availability (Hunt et al. 1999). The ideal free distribution model predicts, however, that patches of high food availability decline in profitability as the number of individual competitors for this shared resource increase in a patch (Fretwell \& Lucas 1969). Indeed, spatial segregation is one of the mechanisms species may use to minimize competition, thereby allowing the coexistence of species with similar resource requirements within a region (Navarro et al. 2009, Quillfeldt et al. 2013, Clay et al. 2016). When food resources are

() The authors 2019. Open Access under Creative Commons by Attribution Licence. Use, distribution and reproduction are unrestricted. Authors and original publication must be credited. 
abundant, however, foraging in association with other species may be beneficial for a number of reasons, such as enhanced prey accessibility (Hoffman et al. 1981, Clua \& Grosvalet 2001, Goyert et al. 2014).

To understand the mechanisms driving seabird distributions at sea, researchers commonly use distributional data from at-sea surveys or tracking devices in combination with measures of ocean productivity (e.g. chl a) as well as physical factors that are both static (e.g. bathymetry, distance to colony) and dynamic (e.g. sea surface temperature [SST], salinity; Ainley et al. 2005, Nur et al. 2011). Researchers often rely on biophysical factors as proxies of prey habitat to explain predator distributional patterns (e.g. Ainley et al. 2005, Amorim et al. 2009), but some studies use direct measures of prey distribution and density (e.g. Ainley et al. 2009, Goyert et al. 2018). Although proxies of prey habitat can sometimes effectively predict predator species distribution when prey distribution is unknown (e.g. Torres et al. 2008), the mechanisms that underscore these associations are often unclear. Predators that consume similar prey types and sizes may also negatively or positively influence the distributional patterns of each other (e.g. Ainley et al. 2009). For instance, foraging in close association with other predators can enhance prey capture rates through prey herding (Evans 1982, Ballance et al. 1997, Clua \& Grosvalet 2001, Hebshi et al. 2008, Goyert et al. 2014) or dispersal of aggregated prey (Thiebault et al. 2016). Indeed, surface-feeding seabirds may rely on subsurface predators, such as tuna (Hebshi et al. 2008) or diving seabirds (Hoffman et al. 1981), to drive prey to the ocean surface, thereby enhancing prey accessibility and capture rates. Seabirds also may cue to the foraging activities of each other (i.e. local enhancement) to minimize energy expenditure while searching for prey (Silverman et al. 2004, Thiebault et al. 2014, Bairos-Novak et al. 2015). In contrast, species might reduce access of other predator species to prey either through indirect interactions, such as reducing access to prey or prey density within a patch through exploitation, or direct interactions, such as food stealing, resulting in avoidance and, ultimately, spatial segregation (Hoffman et al. 1981, Ballance et al. 1997, Maniscalco et al. 2001, Ainley et al. 2003).

Great shearwaters Ardenna gravis (hereafter GRSH) and sooty shearwaters A. grisea (hereafter $\mathrm{SOSH}$ ) are trans-equatorial migrants, and while they breed in large colonies in different regions of the South Atlantic, they have a sympatric distribution during the non-breeding season in the North Atlantic (Brooke 2004). During non-breeding, both species appear to have a similar diet, based on stomach content analysis (e.g. euphausiids, capelin, squid, herring; Brown et al. 1981) as well as stable isotope and fatty acid signatures (Ronconi et al. 2010, Carvalho \& Davoren 2019). Both species are also present in large non-breeding aggregations within coastal regions of the North Atlantic (e.g. Gulf of Maine, Bay of Fundy, Newfoundland), which are often associated with high-density prey aggregations (Brown et al. 1981, Ronconi et al. 2010, Hedd et al. 2012, Davoren 2013a, Powers et al. 2017). In coastal Newfoundland, capelin Mallotus villosus is a key forage fish that is the main prey of many predators (Carscadden et al. 2002, Burke \& Montevecchi 2008, Krumsick \& Rose 2012), including GRSH and SOSH (Carvalho \& Davoren 2019). Capelin migrate from offshore wintering areas to coastal regions to spawn during the summer (Davoren et al. 2006), resulting in a highly abundant pulsed source of prey close to shore that is associated with the arrival of non-breeding GRSH and $\mathrm{SOSH}$ (Davoren 2013a). During the capelin spawning season, $>95 \%$ of the fish sampled in trawls (by number) within the study area is capelin (Davoren et al. 2006), and multiple marine predators (breeding and nonbreeding species) tend to shift their diet to rely more on capelin (Piatt 1990, Carscadden et al. 2002, Regular et al. 2009, Gulka et al. 2017). As capelin cease feeding while inshore to spawn (Davoren et al. 2006), their distribution is primarily associated with beach or shallow water $(<40 \mathrm{~m})$ spawning sites (Penton \& Davoren 2012) along with coastal $(<50 \mathrm{~m})$ migratory routes linking nearshore pre-spawning staging areas to spawning sites (Davoren et al. 2006, Davoren 2013b). As such, commercial fishing effort primarily targets capelin during this period, but the capelin catch in the study area (Notre Dame Bay) is minimal relative to other Newfoundland bays and is concentrated in shallow areas $(<20 \mathrm{~m}$; DFO 2018).

The objective of this study was to describe the distributional patterns of non-breeding GRSH and $\mathrm{SOSH}$ in a coastal area of northeastern Newfoundland during the capelin spawning season (i.e. high prey availability) and examine the importance of biophysical variables (i.e. SST, depth, chl $a$, fish prey and predator densities) that explain these patterns. Specifically, we test the hypothesis that the distributional patterns of each shearwater species are primarily influenced by capelin density and distributional patterns within this non-breeding foraging area. Given the high abundances of capelin in the study area, suggesting a low probability of prey limitation, shared prey types between shearwater species, and potential energetic benefits of foraging in close asso- 
ciation with similar species, we also hypothesized that GRSH and SOSH distributional patterns would explain each other's distribution and predicted that the distributions of these 2 species would be highly associated at sea. Testing these hypotheses will determine biophysical factors explaining the distributional patterns of GRSH and SOSH during their nonbreeding season, for which little information exists.

\section{MATERIALS AND METHODS}

\subsection{Study area}

The study was conducted off the northeastern coast of Newfoundland $\left(49^{\circ}-50^{\circ} \mathrm{N}, 53^{\circ}-54^{\circ} \mathrm{W}\right.$; Fig. 1). In the study area, spawning capelin migrate toward the coast in a deep water $(>200 \mathrm{~m})$ trench ( Line 1, Fig. 1), where they remain in a pre-spawning staging area close to the coast to complete gonadal development throughout July (Davoren et al. 2006). Spawning capelin then move northward along the coast in shallow areas (i.e. $<50 \mathrm{~m}$ ) to spawn on beaches and at shallow water sites (15-40 $\mathrm{m}_{i}$ Fig. 1) during midto late July (Davoren et al. 2006, Davoren 2013b). A biological hotspot, where high abundances of many marine predator species aggregate, forms over a

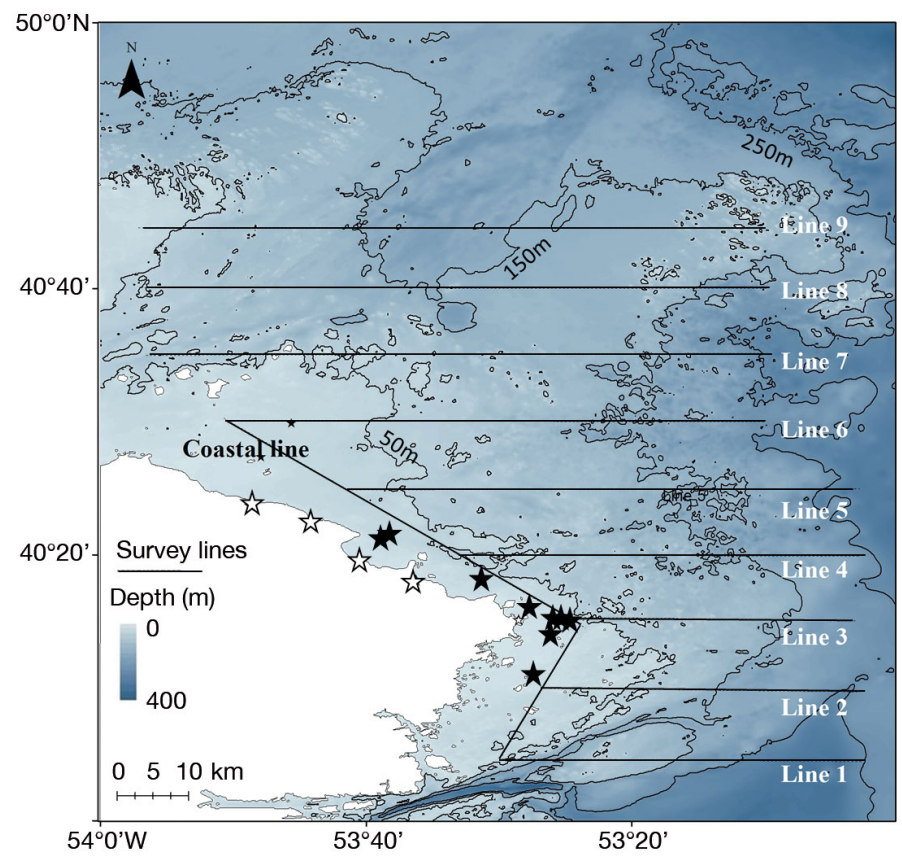

Fig. 1. Study area on the northeastern coast of Newfoundland, highlighting survey lines (coastal line and Lines 1-9) and known capelin spawning sites at beaches (open stars) and in shallow water (black stars). Depth contours (50, 150 and $250 \mathrm{~m}$ ) are indicated cluster of annually persistent shallow water spawning sites (inshore section of Line 3, Fig. 1; Penton \& Davoren 2012, Davoren 2013a). Within this hotspot, GRSH and SOSH represent 2 of the most abundant species present during the summer, with both species comprising at least half of all seabird predators (by number; Davoren 2013a), together with breeding common murres Uria aalge and northern gannets Morus bassanus (Davoren 2007, 2013a).

\subsection{At-sea surveys}

At-sea surveys were repeatedly conducted on commercial fishing vessels during late July to early August of 2007, 2009 to 2012, and 2014 to 2016 (Table 1). The survey timing coincided with the capelin spawning season, when capelin were highly abundant in the study area. The survey consisted of 9 transect lines (hereafter line) across the shelf (eastwest) and 1 line along the coast (south-north; Fig. 1). All lines were not conducted annually due to limited ship time, resulting in 200 to $450 \mathrm{~km}$ surveyed each year. Some adjacent lines (i.e. Lines 3-4,6-7) had similar seabird densities within years (Davoren 2007, 2013a); thus, during years of reduced effort, one of these lines was randomly surveyed along with lines where seabird densities were historically higher (i.e. coastal line, Line 1, Line 4; Fig. 1, Table 1). During the surveys, strip transect methods were used (Method I, Tasker et al. 1984), whereby 2 observers continuously recorded the number of each seabird species flying and sitting separately within a $300 \mathrm{~m}$ strip off the port side of a $10 \mathrm{~m}$ vessel moving at a constant speed (range: $9-11 \mathrm{~km} \mathrm{~h}^{-1}$ ). Based on earlier surveys (2000-2003) in the study area (Davoren 2007), we determined that the probability of detecting birds at sea decreased at distances beyond $300 \mathrm{~m}$, similar to other studies (Barbraud \& Thiebot 2009). Therefore, we counted birds within the $300 \mathrm{~m}$ strip only to ensure consistency among observers across years. We recorded the number of each species directly into a laptop (Birds \& Beasty Counter software, version 1.0, 1998; D. Senciall, Fisheries and Oceans Canada) along with behavioural descriptions (on water or flying). Some bird species fly faster than vessels during surveys, increasing their encounter rates (Spear et al. 1992); therefore, we only considered the number of shearwaters on the water to avoid overestimating the number of birds in the area. The software appended a latitude, longitude and time to each count entered. Capelin density was quantified simultaneously using a BioSonics DTX 6000 scientific 
Table 1. Date range, lines surveyed and total distance covered within each annual survey conducted during the summer (July-August) on the northeastern Newfoundland coast and the percentage of $4 \mathrm{~km}^{2}$ bins in which sooty shearwaters (SOSH) were present (i.e. overlapped) with great shearwaters (GRSH; and vice versa), average density (minimum and maximum in parentheses) of shearwaters on the water in $4 \mathrm{~km}^{2}$ bins when birds were present, and ratio of GRSH to SOSH observed during each survey. Note the survey lines are the same as in Fig. 1. CL: coastal line; L: line

\begin{tabular}{|c|c|c|c|c|c|c|c|c|}
\hline \multirow{2}{*}{ Year } & \multirow{2}{*}{ Dates } & \multirow{2}{*}{$\begin{array}{c}\text { Lines } \\
\text { surveyed }\end{array}$} & \multirow{2}{*}{$\begin{array}{l}\text { Total distance } \\
\text { surveyed }(\mathrm{km})\end{array}$} & \multicolumn{2}{|c|}{- GRSH } & \multicolumn{2}{|c|}{$-\mathrm{SOSH}-$} & \multirow{2}{*}{$\begin{array}{c}\text { GRSH:SOSH } \\
\text { ratio }\end{array}$} \\
\hline & & & & $\begin{array}{c}\text { Overlap with } \\
\text { SOSH (\%) }\end{array}$ & $\begin{array}{l}\text { Bird density, } \\
\text { birds km-2 }\end{array}$ & $\begin{array}{c}\text { Overlap with } \\
\text { GRSH (\%) }\end{array}$ & $\begin{array}{l}\text { Bird density, } \\
\text { birds } \mathrm{km}^{-2}\end{array}$ & \\
\hline 2007 & $\begin{array}{l}\text { Jul 24-26; } \\
\text { Jul 29-31 }\end{array}$ & CL; L1, 3-7, 9 & 403.6 & 73 & $\begin{array}{c}20.3 \\
(0.5-107.8)\end{array}$ & 78 & $\begin{array}{c}37.7 \\
(0.5-288.9)\end{array}$ & 0.68 \\
\hline 2009 & $\begin{array}{c}\text { Jul 31; } \\
\text { Aug 7, 9-10 }\end{array}$ & CL; L1-9 & 453.1 & 68 & $\begin{array}{c}21.3 \\
(0.7-440.1)\end{array}$ & 73 & $\begin{array}{c}42.4 \\
(0.7-734.9)\end{array}$ & 0.57 \\
\hline 2010 & $\begin{array}{c}\text { Jul 31-Aug } 3 \\
\text { Aug } 7\end{array}$ & CL; L1-2, 4-8 & 388.7 & 90 & $\begin{array}{c}10.5 \\
(2.22-22.9)\end{array}$ & 60 & $\begin{array}{c}168.5 \\
(1.1-625.0)\end{array}$ & 0.05 \\
\hline 2011 & $\begin{array}{c}\text { Jul 27, 29-30; } \\
\text { Aug } 2-3\end{array}$ & CL; L1-4, 6-8 & 361.7 & 94 & $\begin{array}{c}4.5 \\
(0.9-13.8)\end{array}$ & 52 & $\begin{array}{c}62.6 \\
(0.5-333.3)\end{array}$ & 0.05 \\
\hline 2012 & Jul 29-Aug 2 & CL; L1-4, 6-8 & 355.5 & 59 & $\begin{array}{c}34.6 \\
(0.5-217.4)\end{array}$ & 76 & $\begin{array}{c}35.0 \\
(0.4-133.8)\end{array}$ & 1.45 \\
\hline 2014 & $\begin{array}{c}\text { Jul 27-28, 31; } \\
\text { Aug } 4\end{array}$ & $\mathrm{CL}_{;} \mathrm{L} 1-4,7-8$ & 259.4 & 57 & $\begin{array}{c}79.3 \\
(1.1-895.7)\end{array}$ & 77 & $\begin{array}{c}72.3 \\
(0.5-425)\end{array}$ & 1.62 \\
\hline 2015 & $\begin{array}{c}\text { Jul 31; } \\
\text { Aug 2, } 15\end{array}$ & CL; L1, 3-4 & 212.1 & 43 & $\begin{array}{c}3.2 \\
(1.0-13.3)\end{array}$ & 45 & $\begin{array}{c}25.9 \\
(0.9-94.4)\end{array}$ & 0.11 \\
\hline 2016 & $\begin{array}{c}\text { Aug 8-10 } \\
12\end{array}$ & CL; L1, 3-4, 6 & 209.1 & 64 & $\begin{array}{c}77.4 \\
(1.1-506.1)\end{array}$ & 69 & $\begin{array}{c}49.1 \\
(0.8-326.7)\end{array}$ & 1.86 \\
\hline \multicolumn{3}{|c|}{ Total $/$ mean $\pm \mathrm{SD}$} & 2643.2 & 66 & $31.2 \pm 90.3$ & 68 & $54.8 \pm 107.4$ & 0.64 \\
\hline
\end{tabular}

echosounding system, whereby the transducer was towed along the starboard side at a depth of $\sim 1 \mathrm{~m}$ below the surface, as described in Davoren et al. (2006). In brief, the sounder was operated through a $70 \mathrm{kHz}$ split beam transducer $\left(5.5^{\circ}\right.$ full narrow beam width, $15^{\circ}$ full wide beam width) calibrated with a tungsten carbide sphere and mounted in a towed body. The sounder was operated at 1 ping $\mathrm{s}^{-1}$ and pulse duration of $0.4 \mathrm{~ms}$. Raw high-resolution hydroacoustic data (volume backscattering coefficient, $s_{\mathrm{v}}$ ) were continuously acquired above a threshold of -90 dB. Echoview software (version 4, SonarData, Myriax Software) was used to omit acoustic signals within $0.5 \mathrm{~m}$ of the seabed if they could not be distinguished from the seafloor (e.g. side-lobing; Simmonds \& MacLennan 2005). To quantify acoustic biomass (area backscattering coefficient, $s_{\mathrm{a}}, \mathrm{m}^{2} \mathrm{~m}^{-2}$; MacLennan et al. 2002), we integrated acoustic signals using a minimum $s_{\mathrm{v}}$ threshold of $-80 \mathrm{~dB}$ in $100 \mathrm{~m}$ segments along the survey. Using a published target strength-length relationship for capelin (Rose 1998) along with the mean length of capelin collected in the study area each year, $s_{\mathrm{a}}$ was converted into the number of individuals per square meter of capelin present in each $100 \mathrm{~m}$ segment during each survey. Total seabird counts and capelin density were calculated for each $100 \mathrm{~m}$ segment along each line.

To examine the variables underlying the distribution of each shearwater species in the study area, we obtained bathymetry (depth, m), SST $\left({ }^{\circ} \mathrm{C}\right)$ and $\operatorname{chl} a$ concentration $\left(\mathrm{mg} \mathrm{m}^{-3}\right)$. Bathymetry data (100 m resolution) were obtained from the Canadian Hydrographic Service, while satellite-derived SST and chl a data (MODIS Aqua; $4 \mathrm{~km}^{2}$ resolution) were downloaded from the Goddard Earth Sciences Data and Information Services Center at the NASA Web site (https://disc.gsfc.nasa.gov). The spatial resolution available for SST and chl a was $4 \mathrm{~km}^{2}$, and all data were compiled into each $4 \mathrm{~km}^{2}$ bin within the study area using ArcGIS Desktop 10.3 ESRI ${ }^{\circledR}$ (Spatial Join tool). This spatial scale has been used in previous studies in the study area (Davoren et al. 2003, Davoren 2013a), as it represents the range at which seabirds on the water could visually detect the foraging activities of other birds $(\sim 4.5 \mathrm{~km}$; Haney et al. 1992). The mean SST and chl a during the period that surveys were conducted (July 19-August 13) in each year were used. When the environmental data (SST and chl a) were missing in a particular $4 \mathrm{~km}^{2}$ bin, the value from an adjacent $4 \mathrm{~km}^{2}$ bin was used. Fish den- 
sity (ind. $\mathrm{m}^{-2}$ ) was averaged over all $100 \mathrm{~m}$ survey segments in each $4 \mathrm{~km}^{2}$ bin, as was depth, while the total number of each shearwater species on the water in each $4 \mathrm{~km}^{2}$ bin was used. For distributional maps (Figs. S1 \& S2 in the Supplement at www.int-res.com/ articles/suppl/m627p001_supp.pdf) and in Table 1, bird densities were calculated as the total number of each shearwater species on the water in each $4 \mathrm{~km}^{2}$ bin divided by the total area surveyed within that bin (i.e. no. of $100 \mathrm{~m}$ survey segments multiplied by $0.03 \mathrm{~km})$.

\subsection{Statistical analysis}

All statistical analyses were performed using $\mathrm{R}$ (version 3.4.0, R Core Team 2017). Environmental data were examined for differences among years using non-parametric Wilcoxon tests. The number of birds in the $4 \mathrm{~km}^{2}$ bins contained a large number of zeros $\left(>70 \%\right.$ of bins $\left.\mathrm{yr}^{-1}\right)$; thus, we used a zeroaltered (hurdle) negative binomial model (pscl package; Zeileis et al. 2008) to determine the important predictor variables underlying the distribution of each shearwater species, similar to Nishizawa et al. (2015) and Goyert et al. (2018). The hurdle model is composed of 2 parts: a binomial-based part, which identifies the factors explaining presence (i.e. number of birds greater than zero) versus absence (i.e. number of birds equal to zero), and a count-based part, which identifies the factors explaining the number of birds where the birds were present (Zuur et al. 2009). For these models, the total number (count) of GRSH or SOSH within each $4 \mathrm{~km}^{2}$ bin was used as the response variable. Each $4 \mathrm{~km}^{2}$ bin had a different survey effort (i.e. number of $100 \mathrm{~m}$ survey segments); therefore, we added the survey effort as an offset within the model. The predictor (explanatory) variables used in both the presence-absence and countbased models consisted of biotic factors (i.e. fish density, chl a) and abiotic factors (i.e. SST, depth). Fish density was log transformed to allow a normal distribution. We also included the number of the other shearwater species on the water as a predictor variable to test our second hypothesis and identify whether GRSH and SOSH were highly associated at sea (Goyert 2014). Although Manx shearwaters Puffinus puffinus were occasionally observed during surveys, we consider only GRSH and SOSH here. The total counts of seabird species other than shearwaters on the water, primarily breeding common murres and northern gannets (Davoren 2007, 2013a), were also included as a predictor variable in the models. All predictor variables were $z$-scored (standardized) to allow comparison among these variables with different scales and to determine which predictors had the most influence on presence and/or counts of each shearwaters species in each model (Zuur et al. 2007).

Prior to running models, we examined correlations (Spearman) between the covariates and found that depth was highly correlated with chl a ( $\mathrm{r}>0.7)$. Therefore, we excluded chl a from further analyses and only included depth during model selection. As capelin cease feeding prior to spawning (Davoren et al. 2006) and spawning sites of capelin are located in shallow areas (<40 m; Penton \& Davoren 2012), depth would likely be more indicative of distributional patterns of both shearwaters (Davoren 2013a) and capelin (Davoren et al. 2006) than chl a. We initially ran the full model (i.e. all predictor variables included) for each shearwater species with year as a discrete random variable (Table S1 in the Supplement) and found that year explained much of the variance in the GRSH dataset (count: $75.7 \%$; binomial: $33.9 \%$ ) but not in the SOSH dataset (count: $<0.01 \%$; binomial: $6.6 \%$ ). Owing to this interannual variability (especially for GRSH), we were interested to examine how the predictor variables explaining the presence and number of GRSH and SOSH differed among years; thus, we ran separate models by year, as other similar studies have done (e.g. Ainley et al. 2009, Goyert et al. 2018). The by-year models were initially run with an interaction between the number of the other Shearwater $\times$ Prey density, but the interaction was not statistically significant; therefore, the interaction was omitted from the by-year analysis but was left in the full model (with year as a discrete random variable; see Table S1). Within each year, we used Akaike's information criterion corrected for small sample size $\left(\mathrm{AIC}_{\mathrm{C}}\right)$ to select the best $\left(\Delta \mathrm{AIC}_{\mathrm{C}}=0\right)$ and competitive models $\left(\Delta \mathrm{AIC}_{\mathrm{C}}<2\right)$. The model-averaged parameter estimates for each predictor variable along with its relative importance were then calculated across all competitive models (MuMIn package; Barton 2018). The relative importance (RI) of each predictor variable was calculated by summing the Akaike weights of all competitive models in which that variable was present (Burnham \& Anderson 2002).

In survey-based species distributions, spatial autocorrelation can violate the assumption of independence between samples (Dormann 2007), where samples closer in space will be more similar relative to samples farther apart. By combining survey data into $4 \mathrm{~km}^{2}$ bins, we reduced the spatial correlation among nearby observations during the survey. In addition, 
we calculated Moran's I (ape package; Paradis et al. 2004) for surveys in each year to test for spatial correlation (Dormann 2007, Nishizawa et al. 2015). Although values were mostly statistically significant $(p<0.05)$, indexes were lower than 0.1 , indicating a lower spatial correlation within each year's dataset for GRSH and SOSH.

\section{RESULTS}

In total, $2643 \mathrm{~km}$ were surveyed during the summer (July-August) in coastal Newfoundland, with 7743 GRSH and 12114 SOSH counted on the water (Table 1). Other common species present on the water during the surveys in relatively high numbers were breeding species, including common murres (13512) and northern gannets (657), as reported during previous studies in the study area (Davoren 2007, 2013a). The ratios of GRSH to SOSH and densities of the 2 shearwaters species varied widely among years. Higher densities of GRSH relative to SOSH were observed during 2012, 2014 and 2016, whereas the opposite was the case during 2010, 2011 and 2015 (Table 1). The percentage of $4 \mathrm{~km}^{2}$ bins that SOSH were present with GRSH (and vice versa) varied between 43 and $94 \%$ (Table 1).

\subsection{Environmental data}

Environmental conditions varied significantly among years (Table 2). Indeed, the annual average SST ranged from 9.94 to $16.69^{\circ} \mathrm{C}$ and differed significantly among years $\left(\chi^{2}=690.98, \mathrm{p}<0.0001\right)$. The warmest years surveyed were 2012 and 2014,

Table 2. Mean $\pm \mathrm{SD}$ of sea surface temperature $\left(\mathrm{SST}_{i}{ }^{\circ} \mathrm{C}\right)$ and fish density (ind. $\mathrm{m}^{-2} \times 10^{3}$ ) in each survey year on the northeastern coast of Newfoundland during the survey period (Jul 17-Aug 12). Significantly different values $(p<0.05)$ among years are indicated by different letters, while values that are not significantly different $(p>0.05)$ are indicated by the same letters

\begin{tabular}{|ccc|}
\hline Year & SST $\left({ }^{\circ} \mathrm{C}\right)$ & Fish density (ind. $\left.\mathrm{m}^{-2} \times 10^{3}\right)$ \\
\hline 2007 & $13.27 \pm 1.23^{\mathrm{e}}$ & $0.31 \pm 2.56^{\mathrm{ab}}$ \\
2009 & $13.77 \pm 0.49^{\mathrm{de}}$ & $0.26 \pm 1.89^{\mathrm{ab}}$ \\
2010 & $13.82 \pm 0.51^{\mathrm{d}}$ & $0.19 \pm 0.94^{\mathrm{b}}$ \\
2011 & $9.94 \pm 0.55^{\mathrm{g}}$ & $0.16 \pm 0.65^{\mathrm{b}}$ \\
2012 & $15.81 \pm 0.91^{\mathrm{b}}$ & $0.15 \pm 0.72^{\mathrm{ab}}$ \\
2014 & $16.69 \pm 1.89^{\mathrm{a}}$ & $1.90 \pm 11.03^{\mathrm{ab}}$ \\
2015 & $11.93 \pm 1.73^{\mathrm{f}}$ & $0.23 \pm 1.72^{\mathrm{ab}}$ \\
2016 & $14.38 \pm 0.83^{\mathrm{c}}$ & $2.88 \pm 18.08^{\mathrm{a}}$ \\
\hline
\end{tabular}

whereas the coldest years were 2011 and 2015 (Table 2). The annual average fish density also varied significantly among years $\left(\chi^{2}=41.19, \mathrm{p}<0.001\right)$, with higher densities in 2016 and lower densities in 2010 and 2011 (Table 2).

\subsection{Shearwater presence and numbers}

For GRSH, the number of other shearwater species (i.e. $\mathrm{SOSH}_{i}$ other shw in Table 3) on the water was included in the model as a predictor variable in all binomial (presence-absence) and count (numbers) components of the hurdle models in all years with high importance $(\mathrm{RI}=1.0)$, although this predictor variable was not statistically significant in a few years (count: 2009, 2011, 2015; binomial: 2014; Table 3). Although these trends were similar for $\mathrm{SOSH}$, the number of the other shearwater species (i.e. GRSH) on the water was statistically significant for SOSH in fewer years (count: 2015, 2016; binomial: 2007, 2009, 2012; Table 3). In all cases, there was a positive relationship between the presence and number of one shearwater species with the other, and this predictor variable often explained more of the variation in presence and/or number than other predictors (i.e. higher parameter estimates; Table 3). Additionally, both species showed high overlap (45-78\%) within $4 \mathrm{~km}^{2}$ bins during each survey (Table 1), or aggregations were in close proximity (i.e. adjacent $4 \mathrm{~km}^{2}$ bins; Figs. S1 \& S2). In contrast, the number of other species on the water (other sp in Table 3 ) had low importance for GRSH and SOSH but was statistically significant with high relative importance $(\mathrm{RI}=$ 1.0 ) in 1 year for GRSH (count: none; binomial: 2014; Table 3) and 2 years for SOSH (count: 2016; binomial: 2014; Table 3).

The relative importance of SST was typically low for GRSH (mostly RI < 0.4) and was only present in models and statistically significant with high relative importance $(\mathrm{RI}=1)$ in 2 years (count: 2010, 2011; binomial: 2011; Table 3). In general, when present in the model, there was typically a negative relationship between SST and GRSH numbers, where higher GRSH numbers occurred at lower temperatures (Table 3). In contrast, the relationship between SST and SOSH numbers was typically positive, with higher SOSH numbers associated with higher temperatures (Table 3); however, SST was only statistically significant with moderate relative importance $(\mathrm{RI}=0.58-0.86)$ in 3 years (count: 2014, 2015, 2016; binomial: none; Table 3). In contrast, depth was present and statistically significant in more models 
Table 3. Parameter estimates from the zero-altered models (count and binomial) for the distribution of great shearwaters (GRSH) and sooty shearwaters (SOSH) in coastal Newfoundland during July to August 2007, 2009 to 2012, and 2014 to 2016, with relative importance (RI; sum of Akaike weights) and number of competitive models present (n). Predictor variables include sea surface temperature $\left(\mathrm{SST},{ }^{\circ} \mathrm{C}\right)$, depth $(\mathrm{m})$, fish density (logfish, ind $\mathrm{m}^{-2}$ ), number of the other shearwater species (i.e. SOSH or GRSH; other shw) and number of all other seabird species, excluding shearwaters (other sp). Bold: predictor variables that significantly influenced bird numbers and presence $\left({ }^{*} \mathrm{p}<0.05,{ }^{* *} \mathrm{p}<0.01,{ }^{* * *} \mathrm{p}<0.0001\right)$ and were present in all competitive models $(\mathrm{RI}=1.00)$. If parameter estimates for a predictor variable are not given, the predictor variable was not included in any competitive models

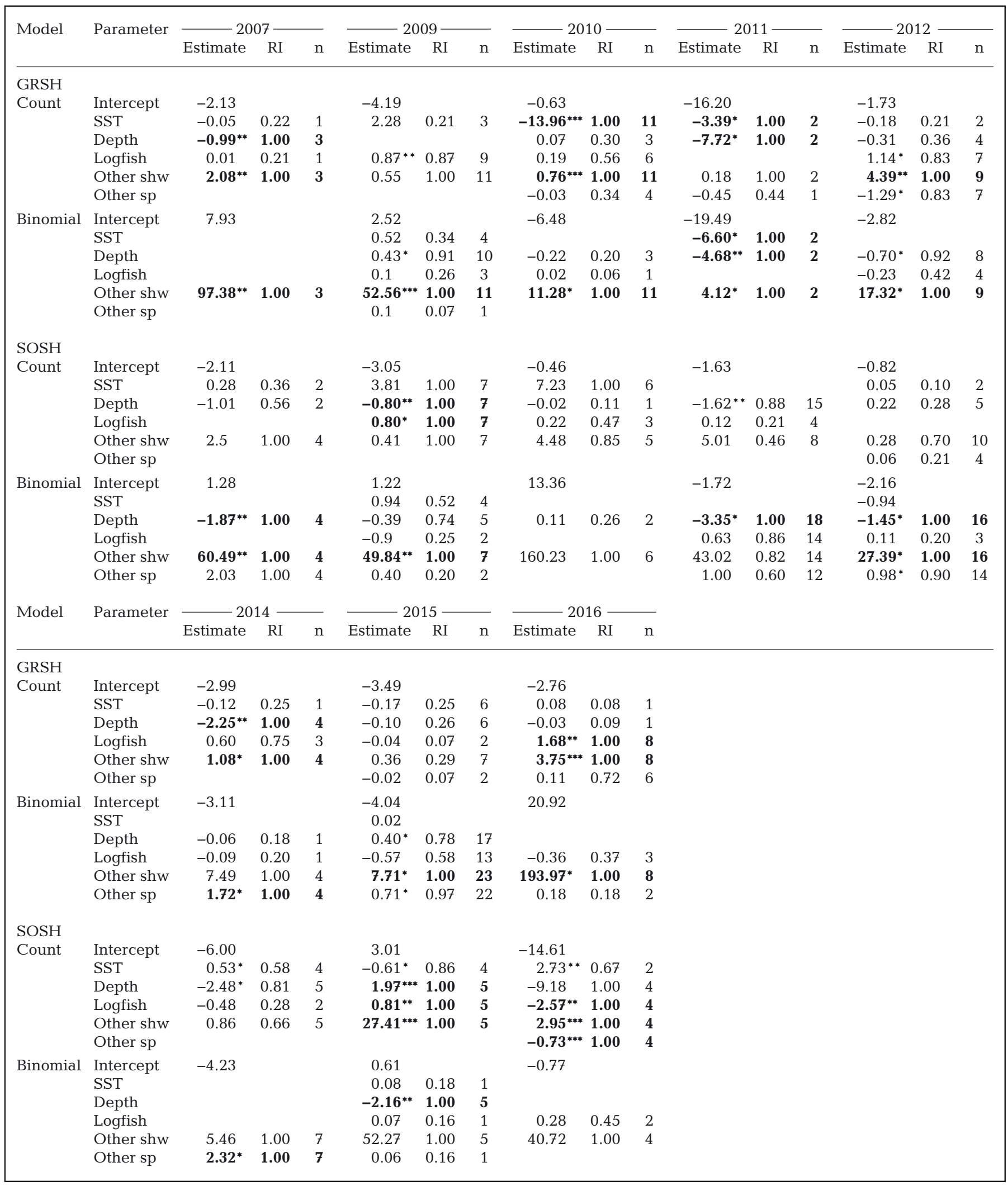


with high relative importance $(\mathrm{RI}=1.0)$ in more years for GRSH (count: 2009, 2011, 2014; binomial: 2011) and SOSH (count: 2009, 2015; binomial: 2007 , 2011, 2012, 2015; Table 3). Shallow areas typically had higher numbers and presence of both shearwater species. Finally, the relative importance of fish density (logfish) was typically low (mostly RI < 0.4), but fish density was present in models and statistically significant with high relative importance in 1 year for GRSH (count: 2016; binomial: none; Table 3) and 3 years for SOSH (count: 2009, 2015, 2016; binomial: none; Table 3), where higher numbers of GRSH and SOSH on the water were associated with high fish density.

\section{DISCUSSION}

The presence and number of GRSH and SOSH were positively influenced by the number of the other sympatric shearwater species, especially for GRSH, but were not influenced by other seabird species, primarily common murres and northern gannets. Together with the high spatial overlap of GRSH and SOSH at sea, these findings suggest that speciesspecific foraging habitat preferences are similar and that the benefits of foraging in close association may outweigh costs. This was predicted, as these 2 shearwater species have a similar diet during non-breeding (Brown et al. 1981, Ronconi et al. 2010, Carvalho 2018) and the high abundance of spawning capelin in coastal Newfoundland suggests that prey limitation in the area is unlikely. SST had minimal and varied influence on shearwater numbers and presence among years, possibly because SST varied little in

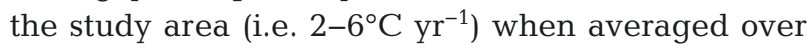
the survey period within each year. Although fish density was more important than SST in explaining the presence and number of both shearwater species, depth was the most important of these 3 variables, with both species being primarily found together in shallow $(<50 \mathrm{~m})$ areas close to the coast (Figs. S1 \& S2). Although fish density also was primarily distributed in shallow areas, reflecting the locations of capelin spawning sites and migratory routes to spawning sites in the area, high-density areas of shearwaters and fish did not overlap to a large extent at the spatial scale of analysis $\left(4 \mathrm{~km}^{2}\right)$. Overall, findings suggest that depth (or distance from shore) and the distribution of other shearwaters may provide important cues for GRSH and SOSH to locate regions of high prey availability along the coast during their non-breeding season in coastal Newfoundland.
The high overlap of both shearwater species and the high variation explained by the other shearwater species (i.e. GRSH or SOSH) all suggest that the costs of foraging in close association when spawning capelin are highly abundant inshore are outweighed by the benefits. Benefits of foraging together may include increased prey accessibility and lower energy expenditure while searching for prey. As SOSH dive up to $70 \mathrm{~m}$ (Weimerskirch \& Sagar 1996, Shaffer et al. 2009), while GRSH dive up to $19 \mathrm{~m}$ (Ronconi et al. 2010), SOSH may chase prey closer to the surface to benefit GRSH, which may explain GRSH distributional patterns being more influenced by SOSH than vice versa. Additionally, the use of local enhancement, or cueing to the foraging activities of seabirds, can increase net energy gain by reducing the time spent searching for prey, as it is presumably easier to detect feeding birds than aggregations of undetected prey (Grünbaum \& Veit 2003, Thiebault et al. 2014). As GRSH and SOSH appear to feed on similar prey types during the nonbreeding season in coastal Newfoundland (Brown et al. 1981, Carvalho \& Davoren 2019) and other regions of the North Atlantic (Ronconi et al. 2010), these species may cue to the foraging activities of each other to locate prey. Indeed, local enhancement has been suggested for seabird species when other marine predators have been identified as important predictors of their at-sea distribution (e.g. Davoren et al. 2003, Goyert 2014, Goyert et al. 2018). An experiment conducted in the study area revealed that some species of seabirds (i.e. common murres, northern gannets) cue to decoys (i.e. plastic bird models; Bairos-Novak et al. 2015) but do so to a lesser extent during high capelin biomass (i.e. spawning) relative to low capelin biomass (i.e. prespawning). It also is possible that the high spatial overlap of GRSH and SOSH at sea may simply reflect similar species-specific foraging habitat preferences, whereby they aggregate together within larger areas of high capelin density.

At the spatial scale of our analysis $\left(4 \mathrm{~km}^{2}\right)$, fish density was not an important variable explaining the density and distributional patterns of either shearwater species to a great extent. Relative to fish density, distributional patterns of each shearwater species appeared to be mainly influenced by depth, suggesting that birds may be cueing to other environmental features, such as proximity to the coast, which was correlated with depth. Similarly, seabird distribution has been explained by depth in other studies, with some species using shallow coastal areas (e.g. SOSH in the Pacific, 
Ainley et al. 2009) and others using slope areas (e.g. Yen et al. 2004, Nur et al. 2011). In our study area, depth is important for predicting capelin distribution (Davoren et al. 2006). Indeed, capelin aggregate near annually persistent spawning beaches and shallow water spawning sites $(<40 \mathrm{~m}$; Penton \& Davoren 2012) prior to and during spawning (Davoren et al. 2006), supporting that shallow areas have predictably higher capelin density. In addition, ephemeral schools of maturing capelin predictably move northward along the coast in shallow regions $(<50 \mathrm{~m})$, where temperature is typically above the lower threshold for capelin spawning (i.e. $2^{\circ} \mathrm{C}_{i}$ Davoren et al. 2006), presumably to locate suitable spawning habitat (Davoren 2013b). Owing to the spatial predictability of capelin aggregations, on both a fine scale (spawning sites) and mesoscale (migratory routes), shearwaters may use memory to return to these specific and general areas, similar to other marine predators in the study area (Davoren et al. 2003, Montevecchi et al. 2009, Gulka \& Davoren 2019). If shearwater species use other features, such as distance to shore (a proxy of depth in our study area), to return to areas where capelin schools are predictably abundant and accessible throughout the water column, this might explain shearwater density and distributional patterns being more influenced by depth than fish density.

As the spatial scale at which predator-prey associations are examined influences the strength of correlations observed and reported (Schneider \& Piatt 1986), the minimal influence of fish density on shearwater distributional and density patterns may also be related to the spatial scale (i.e. $4 \mathrm{~km}^{2}$ ) of our study. Indeed, distributional maps in this study (Figs. S1 \& S2) illustrate that $4 \mathrm{~km}^{2}$ bins with high densities of shearwaters were often found near cells with high densities of fish, suggesting that the spatial correlation between prey and predators would increase with the scale studied, as observed in other studies (e.g. Rose \& Leggett 1990, Fauchald et al. 2000). Additionally, non-linear relationships between predator and prey densities are often reported in the literature (e.g. Piatt 1990), and prey densities above a particular threshold may be needed for shearwaters to aggregate.

Other studies have found that SST can predict seabird aggregations (Hyrenbach et al. 2006, Nishizawa et al. 2015), especially in frontal zones (Abrams 1985, Begg \& Reid 1997), which was not the case in this study. In our study area, the average SST does not vary substantially during the period surveyed, and fronts driving prey distribution did not appear to be present, as documented in other areas (Hoefer 2000, Bost et al. 2009, Scales et al. 2014, Cox et al. 2016). In contrast, capelin aggregate mostly near the seabed in a layer of $>0^{\circ} \mathrm{C}$ water within deep $(>200 \mathrm{~m})$ trenches during their inshore spawning migration on the Newfoundland Shelf (Mowbray 2002) and then occupy depths with $>0^{\circ} \mathrm{C}$ water while inshore during the spawning season (Davoren et al. 2006), suggesting that capelin distribution would be more correlated with bottom temperature than with SST. Indeed, bottom temperature $>2^{\circ} \mathrm{C}$ is a key habitat feature of suitable spawning habitat for capelin (Penton \& Davoren 2012, Crook et al. 2017). As the thermocline occurs between 30 and $50 \mathrm{~m}$ in our study area (Davoren et al. 2006, Penton \& Davoren 2008), SST likely would not be a good proxy of bottom temperature and, thus, capelin habitat.

Overall, the spatial association of both shearwater species during their non-breeding period in coastal Newfoundland indicates that these species use similar foraging habitats, likely due to the high abundance of their main prey species (capelin) in coastal areas $(<50 \mathrm{~m})$. High spatial overlap of these 2 species also suggests that there are minimal costs of foraging in close association, possibly due to enhanced prey accessibility or minimized search effort to locate prey aggregations. Using proxies of depth, such as distance to shore, to return to regions where capelin aggregations are predictably concentrated during the summer, either spawning or migratory routes, may explain the limited influence of fish density relative to depth (i.e. coastal areas $<50 \mathrm{~m}$ ) on shearwater density and distributional patterns. Future experimental studies will be needed, however, to examine the costs and benefits of foraging in close association by these 2 similar shearwater species.

Acknowledgements. Principal funding was provided by a Natural Sciences and Engineering Research Council of Canada (NSERC) Discovery Grant (2007-283212, 2014-06290) and University of Manitoba Faculty of Science Fieldwork Support Program grants (2014-2016) to G.K.D. Ship time funding was provided by NSERC Ship Time grants (372594-09, 387231-10, 403438-11, 419835-2012, 453216-2014, 4701952015, 486208-2016) to G.K.D. and an International Polar Year grant (250396-07). P.C.C. was funded by Science without Borders, Coordination for the Improvement of Higher Education Personnel (Grant No. 001203/2013-04). We are indebted to the captain and crew of the 'Lady Easton' for their assistance with fieldwork. We thank J. Roth, K. Fraser, D. Walker, S. Votier and the 3 anonymous reviewers for providing valuable feedback on the manuscript. 


\section{LITERATURE CITED}

Abrams RW (1985) Environmental determinants of pelagic seabird distribution in the African sector of the Southern Ocean. J Biogeogr 12:473-492

Ainley DG, Ford G, Brown ED, Suryan RM, Irons DB (2003) Prey resources, competition, and geographic structure of kittiwake colonies in Prince William Sound. Ecology 84: 709-723

Ainley DG, Spear LB, Tynan CT, Barth JA, Pierce SD, Ford RG, Cowles TJ (2005) Physical and biological variables affecting seabird distributions during the upwelling season of the northern California Current. Deep Sea Res II 52:123-143

Ainley DG, Dugger KD, Ford RG, Pierce SD and others (2009) Association of predators and prey at frontal features in the California Current: competition, facilitation, and co-occurrence. Mar Ecol Prog Ser 389:271-294

Amorim P, Figueiredo M, Machete M, Morato T, Martins A, Santos RS (2009) Spatial variability of seabird distribution associated with environmental factors: a case study of marine Important Bird Areas in the Azores. ICES J Mar Sci 66:29-40

Bairos-Novak KR, Crook KA, Davoren GK (2015) Relative importance of local enhancement as a search strategy for breeding seabirds: an experimental approach. Anim Behav 106:71-78

Ballance LT, Pitman RL, Reilly SB (1997) Seabird community structure along a productivity gradient: importance of competition and energetic constraint. Ecology 78 : 1502-1518

Barbraud C, Thiebot JB (2009) On the importance of estimating detection probabilities from at-sea surveys of flying seabirds. J Avian Biol 40:584-590

Barton K (2018) MuMIn: multi-model inference. R package version 1.40.4. https://CRAN.R-project.org/package $=$ MuMIn

Begg GS, Reid JB (1997) Spatial variation in seabird density at a shallow sea tidal mixing front in the Irish Sea. ICES J Mar Sci 54:552-565

Bost CA, Cotté C, Bailleul F, Cherel Y and others (2009) The importance of oceanographic fronts to marine birds and mammals of the southern oceans. J Mar Syst 78:363-376

Brooke M (2004) Albatrosses and petrels across the world. Oxford University Press, Oxford

Brown RGB, Barker SP, Gaskin DE, Sandeman MR (1981) The foods of great and sooty shearwaters. Ibis 123:19-30

Burke CM, Montevecchi WA (2008) Fish and chicks: forage fish and chick success in co-existing auks. Waterbirds 31: 372-384

Burnham KP, Anderson DR (2002) Model selection and multimodel inference: a practical information-theoretic approach. Springer Verlag, New York, NY

Carscadden J, Montevecchi WA, Davoren GK, Nakashima BS (2002) Trophic relationships among capelin (Mallotus villosus) and seabirds in a changing ecosystem. ICES J Mar Sci 59:1027-1033

Carvalho PC, Davoren GK (2019) Niche dynamics of sympatric non-breeding shearwaters under varying prey availability. Ibis (in press), doi:10.1111/ibi.12783

Clay TA, Manica A, Ryan PG, Silk JRD, Croxall JP, Ireland L, Phillips RA (2016) Proximate drivers of spatial segregation in non-breeding albatrosses. Sci Rep 6:1-13
Clua É, Grosvalet F (2001) Mixed-species feeding aggregation of dolphins, large tunas and seabirds in the Azores. Aquat Living Resour 14:11-18

Cox SL, Miller PI, Embling C, Scales KL and others (2016) Seabird diving behaviour reveals the functional significance of shelf-sea fronts as foraging hotspots. R Soc Open Sci 3:160317

* Crook KA, Maxner E, Davoren GK (2017) Temperaturebased spawning habitat selection by capelin (Mallotus villosus) in Newfoundland. ICES J Mar Sci 74:1622-1629

* Davoren GK (2007) Effects of gill-net fishing on marine birds in a biological hotspot in the northwest Atlantic. Conserv Biol 21:1032-1045

*Davoren GK (2013a) Distribution of marine predator hotspots explained by persistent areas of prey. Mar Biol 160: 3043-3058

*Davoren GK (2013b) Divergent use of spawning habitat by male capelin (Mallotus villosus) in a warm and cold year. Behav Ecol 24:152-161

*Davoren GK, Montevecchi WA, Anderson JT (2003) Search strategies of a pursuit-diving marine bird and the persistence of prey patches. Ecol Monogr 73:463-481

*Davoren GK, Anderson JT, Montevecchi WA (2006) Shoal behaviour and maturity relations of spawning capelin (Mallotus villosus) off Newfoundland: demersal spawning and diel vertical movement patterns. Can J Fish Aquat Sci63:268-284

DFO (Fisheries and Oceans Canada) (2018) Assessment of capelin in SA2 and Divs. 3KL in 2017. DFO Can Sci Advis Sec Sci Advis Rep 2018/030

* Dormann CF (2007) Effects of incorporating spatial autocorrelation into the analysis of species distribution data. Glob Ecol Biogeogr 16:129-138

Evans PGH (1982) Associations between seabirds and cetaceans: a review. Mammal Rev 12:187-206

Fauchald P, Erikstad KE, Skarsfjord H (2000) Scale-dependent predator-prey interactions: the hierarchical spatial distribution of seabirds and prey. Ecology 81:773-783

Fretwell SD, Lucas HLJ (1969) On territorial behavior and other factors influencing habitat distribution of birds. 1 . Theoretical development. Acta Biotheor 19:16-36

Goyert HF (2014) Relationship among prey availability, habitat, and the foraging behavior, distribution, and abundance of common terns Sterna hirundo and roseate terns S. dougallii. Mar Ecol Prog Ser 506:291-302

Goyert HF, Manne LL, Veit RR (2014) Facilitative interactions among the pelagic community of temperate migratory terns, tunas and dolphins. Oikos 123: $1400-1408$

Goyert HF, Gardner B, Veit RR, Gilbert AT and others (2018) Evaluating habitat, prey, and mesopredator associations in a community of marine birds. ICES J Mar Sci 75: 1602-1612

*Günbaum D, Veit RR (2003) Black-browed albatrosses foraging on Antarctic krill: density-dependence through local enhancement? Ecology 84:3265-3275

*Gulka J, Davoren GK (2019) High individual flexibility in the foraging behavior of a marine predator, the common murre. Mar Biol 166:83

Gulka J, Carvalho PC, Jenkins E, Johnson K, Maynard L, Davoren GK (2017) Dietary niche shifts of multiple marine predators under varying prey availability on the northeast Newfoundland coast. Front Mar Sci 4: $1-11$ 
Haney JC, Fristrup KM, Lee DS (1992) Geometry of visual recruitment by seabirds to ephemeral foraging flocks. Ornis Scand 23:49-62

*Hebshi AJ, Duffy DC, Hyrenbach KD (2008) Associations between seabirds and subsurface predators around Oahu, Hawaii. Aquat Biol 4:89-98

Hedd A, Montevecchi WA, Otley H, Phillips RA, Fifield DA (2012) Trans-equatorial migration and habitat use by sooty shearwaters Puffinus griseus from the South Atlantic during the nonbreeding season. Mar Ecol Prog Ser 449:277-290

Hoefer CJ (2000) Marine bird attraction to thermal fronts in the California current system. Condor 102:423-427

*Hoffman W, Heinemann D, Wiens JA (1981) The ecology of seabird feeding flocks in Alaska. Auk 98:437-456

Hunt GL, Mehlum F, Russell RW, Irons D, Decker MB, Becker H (1999) Physical processes, prey abundance, and the foraging ecology of seabirds. In: Adams NJ, Slotow RH (eds) Proc 22nd Int Ornithological Congr, Durban. BirdLife South Africa, Johannesburg, p 2040-2056

Hyrenbach KD, Veit RR, Weimerskirch H, Hunt GL Jr (2006) Seabird associations with mesoscale eddies: the subtropical Indian Ocean. Mar Ecol Prog Ser 324:271-279

Krumsick KJ, Rose GA (2012) Atlantic cod (Gadus morhua) feed during spawning off Newfoundland and Labrador. ICES J Mar Sci 69:1701-1709

*MacLennan DN, Fernandes PG, Dalen J (2002) A consistent approach to definitions and symbols in fisheries acoustics. ICES J Mar Sci 59:365-369

* Maniscalco JM, Ostrand WD, Suryan RM, Irons DB (2001) Passive interference competition by glaucous-winged gulls on black-legged kittiwakes: a cost of feeding in flocks. Condor 103:616-619

* Montevecchi WA, Benvenuti S, Garthe S, Davoren GK, Fifield D (2009) Flexible foraging tactics by a large opportunistic seabird preying on forage- and large pelagic fishes. Mar Ecol Prog Ser 385:295-306

Mowbray FK (2002) Changes in the vertical distribution of capelin (Mallotus villosus) off Newfoundland. ICES J Mar Sci 59:942-949

* Navarro J, Forero MG, González-Solís J, Igual JM, Bécares J, Hobson KA (2009) Foraging segregation between two closely related shearwaters breeding in sympatry. Biol Lett 5:545-548

* Nishizawa B, Ochi D, Minami H, Yokawa K, Saitoh SI, Watanuki Y (2015) Habitats of two albatross species during the non-breeding season in the North Pacific transition zone. Mar Biol 162:743-752

* Nur N, Jahncke J, Herzog MP, Howar J and others (2011) Where the wild things are: predicting hotspots of seabird aggregations in the California Current System. Ecol Appl 21:2241-2257

Paradis E, Claude J, Strimmer K (2004) APE: analyses of phylogenetics and evolution in R language. Bioinformatics 20:289-290

* Penton PM, Davoren GK (2008) Patterns of larval emergence of capelin (Mallotus villosus) and environmental cues at demersal spawning sites on the northeastern coast of Newfoundland. Can J Fish Aquat Sci 65: 1135-1143

Penton PM, Davoren GK (2012) Physical characteristics of persistent deep-water spawning sites of capelin: importance for delimiting critical marine habitats. Mar Biol Res 8:778-783
Piatt JF (1990) The aggregative response of common murres and Atlantic puffins to schools of capelin. Stud Avian Biol 14:36-51

Powers KD, Wiley DN, Allyn AJ, Welch LJ, Ronconi RA (2017) Movements and foraging habitats of great shearwaters Puffinus gravis in the Gulf of Maine. Mar Ecol Prog Ser 574:211-226

Quillfeldt P, Masello JF, Navarro J, Phillips RA (2013) Yearround distribution suggests spatial segregation of two small petrel species in the South Atlantic. J Biogeogr 40: 430-441

R Core Team (2017) R: a language and environment for statistical computing. R Foundation for Statistical Computing, Vienna. www.r-project.org

Kegular PM, Shuhood F, Power T, Montevecchi WA and others (2009) Murres, capelin and ocean climate: interannual associations across a decadal shift. Environ Monit Assess 156:293-302

* Ronconi RA, Koopman HN, McKinstry CAE, Wong SNP, Westgate AJ (2010) Inter-annual variability in diet of non-breeding pelagic seabirds Puffinus spp. at migratory staging areas: evidence from stable isotopes and fatty acids. Mar Ecol Prog Ser 419:267-282

Rose GA (1998) Acoustic target strength of capelin in Newfoundland waters. ICES J Mar Sci 55:918-923

* Rose GA, Leggett WC (1990) The importance of scale to predator-prey spatial correlations: an example of Atlantic fishes. Ecology 71:33-43

* Scales KL, Miller PI, Embling CB, Ingram SN, Pirotta E, Votier SC (2014) Mesoscale fronts as foraging habitats: composite front mapping reveals oceanographic drivers of habitat use for a pelagic seabird. J R Soc Interface 11: 20140679

Schneider DC, Piatt JF (1986) Scale-dependent correlation of seabirds with schooling fish in a coastal ecosystem. Mar Ecol Prog Ser 32:237-246

* Shaffer S, Weimerskirch H, Scott D, Pinaud D and others (2009) Spatiotemporal habitat use by breeding sooty shearwaters Puffinus griseus. Mar Ecol Prog Ser 391: $209-220$

Silverman ED, Veit RR, Nevitt GA (2004) Nearest neighbors as foraging cues: information transfer in a patchy environment. Mar Ecol Prog Ser 277:25-36

Simmonds E, MacLennan DN (2005) Fisheries acoustics: theory and practice, 2nd edn. Blackwell Science, Oxford

* Spear L, Nur N, Ainley DG (1992) Estimating absolute densities of flying seabirds using analyses of relative movement. Auk 109:385-389

Tasker ML, Jones PH, Dixon TIM, Blake BF (1984) Counting seabirds at sea from ships: a review of methods employed and a suggestion for a standardized approach. Auk 101:567-577

Thiebault A, Mullers RHE, Pistorius PA, Tremblay Y (2014) Local enhancement in a seabird: reaction distances and foraging consequence of predator aggregations. Behav Ecol 25:1302-1310

พ Thiebault A, Semeria M, Lett C, Tremblay Y (2016) How to capture fish in a school? Effect of successive predator attacks on seabird feeding success. J Anim Ecol 85: $157-167$

Torres LG, Read AJ, Halpin PN (2008) Fine-scale habitat modeling of a top marine predator: Do prey data improve predictive capacity? Ecol Appl 18:1702-1717 
Weimerskirch H, Sagar PM (1996) Diving depths of sooty shearwater Puffinus griseus. Ibis 138:786-794

Yen PPW, Sydeman WJ, Hyrenbach KD (2004) Marine bird and cetacean associations with bathymetric habitats and shallow-water topographies: implications for trophic transfer and conservation. J Mar Syst 50:79-99

Zeileis A, Kleiber C, Jackman S (2008) Regression models

Editorial responsibility: Yves Cherel, Villiers-en-Bois, France for count data in R. J Stat Softw 27:1-25. www.jstatsoft. org/v27/i08/

Zuur AF, Ieno EN, Smith GM (2007) Analysing ecological data. Springer, New York, NY

Zuur AF, Ieno EN, Walker N, Saveliev A, Smith GM (2009) Mixed effects models and extensions in ecology with R. Springer, New York, NY

Submitted: January 2, 2019; Accepted: August 23, 2019

Proofs received from author(s): September 20, 2019 